Global Journal of Arts, Humanities and Social Sciences

Vol.10, No.1, pp.54-63, 2021

Print ISSN: 2052-6350(Print)

Online ISSN: 2052-6369(Online)

\title{
ABRAHAM THE FATHER OF FAITH (GEN 12-17) - CHALLENGE TO CHRISTIANS IN NIGERIA
}

\author{
Emmanuel U. Dim
}

\begin{abstract}
Emmanuel U. Dim (2022) Abraham the Father of Faith (Gen 12-17) - Challenge To Christians in Nigeria, Global Journal of Arts, Humanities and Social Sciences, Vol.10, No.1, pp.54-63
\end{abstract}

\begin{abstract}
In Abraham, Israel's first Patriarch, God begins a new development in his plan of the creation and salvation of the world by specially choosing the people of Israel (Gen 12-50), after the general account of the creation and development of mankind from the beginning of the book of Genesis (Gen 1-11). Abraham stands out in his relationship with God and is thus, for those who believe in God and who acknowledge His self-revelation in the OT, the father of faith. Many Christians in Nigeria today suffer from the crisis of faith which often breeds lukewarmness and syncretism in their actual practice of it - and even outright rejection of the same faith in neopaganism. The others who try to remain steadfast, are naturally distracted by the negative activities of these other brothers and sisters with whom they are supposed to be professing the same faith. This paper presents the steadfast legacy in the faith of Abraham, the proto-type of Jesus in the OT, as an enlivening challenge to all Christians, especially here in Nigeria. Abraham's steadfast faith in God, in all the circumstances of his life, challenges the Nigerian Christians of today, as they face all sorts of difficulties in the practice of their faith. It also challenges the institutionalized Churches towards the provision of a sustained catechetical growth for all their members for a more active and vibrant Christian life in our dear country that is today menaced with many religious, social, economic and political problems. To arrive at its goal, this paper employs the exegetico-analytical method of enquiry. In the final analysis, apart from the pertinence of all the points raised in it, this work has the added importance of taking us to the very fertile roots of our faith in God in the person and life of Abraham, thereby helping to engender stronger conviction in the believing audience that would read it.
\end{abstract}

KEYWORDS: Abraham, father, faith, Christians, Nigeria

\section{INTRODUCTION}

"Since we are justified by faith" (Rom 5:1) which manifests in good works (Jas 2:14-17), the theme of faith becomes a very central one in the life of every Christian. On that note, the Church celebrated the "Year of Faith" from the $11^{\text {th }}$ of October 2012 to the $24^{\text {th }}$ of November 2013, the Solemnity of Christ the King. In inaugurating that year, the Supreme Pontiff at that time, Pope Benedict XVI, described it as "a good opportunity to usher the whole Church into a time of

@ECRTD-UK: https://www.eajournals.org/ 
Global Journal of Arts, Humanities and Social Sciences

Vol.10, No.1, pp.54-63, 2021

Print ISSN: 2052-6350(Print)

Online ISSN: 2052-6369(Online)

particular reflection and rediscovery of the faith." 1 This is geared towards greater conviction and reawakening of the potentials of the Christian towards a more actualized Christian life. But this quest for "conviction" as well as the "reawakening of the potentials" are certainly on-going processes in the life of every Christian - hence, the relevance of this article. Abraham's faith is, indeed, a challenge to all Christians, especially Christians in Nigeria.

\section{Faith and its acquisition}

The Letter to the Hebrews, after emphasizing that those who have faith "are saved" (Heb 10:39), describes faith (pistis) as "the assurance of things hoped for, the conviction of things not seen" (Heb 11:1). ${ }^{2}$ These "things" that are "hoped for" concern "the heavenly world" while those "things not seen" are "those of that world." 3 The letter continues its description: "For by it the men of old received divine approval. By faith we understand that the world was created by the word of God, so that what is seen was made out of things which do not appear" (Heb 11:2-3).

Faith is a gift from God who loves mankind and his entire creation. In his infinite goodness and wisdom, it pleased Him "to reveal himself and to make known the mystery of his will. His will was that men should have access to the Father, through Christ, the Word made flesh, in the Holy Spirit, and thus become sharers in the divine nature." 4 Through this revelation to men, God wants to communicate his own divine life to them as "his sons in his only-begotten Son" (cf. Eph 1:4-5). Hence, "by revealing himself God wishes to make them capable of responding to him, and of knowing him and of loving him far beyond their own natural capacity." ${ }^{5}$ Faith, therefore, is the response by man to this self-revelation and invitation from God. It is an act of the understanding and a virtue, divinely infused, whereby we accept as true everything that God has revealed because he has revealed it. Thus, the matter of faith is what God has revealed and teaches us, especially through his Church, to believe. ${ }^{6}$ In other words, "by faith, man completely submits his intellect and his will to God. With his whole being man gives his assent to God the revealer. Sacred Scripture calls this human response to God, the author of revelation, 'the obedience of faith."'7 It is effective and directed towards the future:

1 The Year of Faith (Apostolic Letter of Pope Benedict XVI) (Okpuno: Fides Communications, 2012) 1.

${ }^{2}$ All the biblical citations in this paper will be taken from the Revised Standard Version (RSV).

${ }^{3}$ M. M. BOURKE, "The Epistle to the Hebrews", in R. E. BROWN - J. A. FITZMYER - R. E. MURPHY, ed., The Jerome Biblical Commentary (Bangalore: Theological Publications, 1994) 939940.

${ }^{4}$ The Catechism of the Catholic Church, no. 51 (Nairobi: Paulines, 1994) 44.

${ }^{5}$ The Catechism of the Catholic Church, no. 52, 44.

${ }^{6}$ J. P. LANG, Dictionary of the Liturgy (New York: Catholic Book, 1989) 201.

${ }^{7}$ The Catechism of the Catholic Church, no. 144, 62.

@ECRTD-UK: https://www.eajournals.org/

Journal level DOI: https://doi.org/10.37745/gjahss.2013 
Global Journal of Arts, Humanities and Social Sciences

Vol.10, No.1, pp.54-63, 2021

Print ISSN: 2052-6350(Print)

Online ISSN: 2052-6369(Online)

Faith is thus an effective power directed toward the future. It springs from a direct, personal encounter with the living God. The forward-looking capacity of faith enables an individual to venture courageously and serenely into an unseen future, supported only by the word of God. As a positive orientation of life toward God and his word, faith has the capacity to unveil the future so that solid reality of events as yet unseen can be grasped by the believer. This is clearly an eschatological concept of faith, which the writer wishes to promote among the members of the house church for whom he was pastorally concerned. ${ }^{8}$

From the foregoing points, one then understands the list, by the author of that Letter to the Hebrews, of many people who had acted by faith in the history of Israel, including Abel, Enoch, Noah, Abraham, Jacob, Sarah and Moses (Heb 11:1-40). These men and women "all directed the effective power of faith to realities that for them lay in the future (cf. vv 7,10,13, 27, 31, 35-38), undismayed by harsh circumstances." 9 From all these persons, however, Abraham stands out outstandingly. Hence, his faith "which was 'reckoned to him as righteousness' (Gen 15:6) became a model for NT writers to develop." ${ }^{10}$ It is this "faith" of Abraham which this paper presents as a challenge to Christians, especially in Nigeria.

\section{The Christian}

This is a household word which, I believe, does not need much explanation. But for more clarity and greater specification, the following words are important. A Christian is, broadly speaking, a follower of Christ. "Christian" "is the most common name used today to designate followers of Jesus Christ" and it occurs three times in the NT: Acts 11:26; 26:28; 1 Pet 4:16. It is derived from the Latin, Christianus, and from the Greek, Cristiano,j, (Christianos). But whether from Latin or from Greek, "the term is formed from Christ and indicates Christ's adherents, those who belong to, or are devoted to Christ." 11

Even though there are also other titles with which the followers of Christ were designated right from early times, the name "Christian" is appropriate because it concentrates attention on the centrality of Christ to the person's faith. ${ }^{12}$ Yet, owing to the fact that Abraham's faith is also a model for believing Christians in the NT, as has already been hinted at, it serves as a challenge also for them. A person becomes a Christian by being baptized. Hence, any baptized person could be called a Christian. ${ }^{13}$ Consequently, all who have been baptized in Nigeria, are especially referred to in this article. It is they who are "Christians in Nigeria."

8 W. L. LANE, Hebrews 9-13 (WBC 47B; Nashville: Thomas Nelson, 1991) 329-330.

${ }^{9}$ W. L. LANE, Hebrews 9-13, 330.

${ }^{10}$ D. WILLIAMS, ed., New Concise Bible Dictionary (Leicester: Inter-Varsity, 1989) 165.

${ }^{11}$ M. J. WILKINS, "Christian", in The Anchor Bible Dictionary, Vol. I (New York: Doubleday, 1992) 925.

12 WILLIAMS, ed., New Concise Bible Dictionary, 86.

13 I have treated this theme in detail elsewhere: cf. E. U. DIM, A Christian, a Priest (A Priestly Silver Jubilee Reflection) (Nimo: Rex Charles \& Patrick, 2014) 1-6.

@ECRTD-UK: https://www.eajournals.org/

Journal level DOI: https://doi.org/10.37745/gjahss.2013 
Global Journal of Arts, Humanities and Social Sciences

Vol.10, No.1, pp.54-63, 2021

Print ISSN: 2052-6350(Print)

Online ISSN: 2052-6369(Online)

\begin{abstract}
Abraham: Preliminary Information
Abraham was the son of Terah, husband of Sarah and father of Isaac. He was Israel's first Patriarch, and for Israel and Christianity, as well, "he stands as the father of the faithful."14 There are two forms of the Patriarch's name in the OT, Abram and Abraham. Abram means "the (my) father is exalted" or "exalted father", while Abraham has the traditional etymological meaning of "father of a multitude" 15 consequent upon Yahweh's promise to the Patriarch: "... No longer shall your name be Abram, but your name shall be Abraham; for I have made you the father of a multitude of nations" (Gen 17:4-5).

Abraham was born in Ur. He later moved with Terah his father, Sarah his wife, Nahor and Haran his brothers and Lot his nephew, to Haran. But after his father Terah's death, Abraham moved into Canaan, at the age of $75^{16}$ (Gen 11:26-12:6).
\end{abstract}

\title{
Abraham the Father of Faith (Gen 12-17)
}

The journey of faith of Abraham could, therefore, be said to have begun at Haran, for it is there that God first called him:

Now the Lord said to Abram, "Go from your country and your kindred and your father's house to the land that I will show you. And I will make of you a great nation, and I will bless you, and make your name great so that you will be a blessing. I will bless those who bless you, and him who curses you I will curse; and by you all the families of the earth shall bless themselves" (Gen 12:1-3)

This "call is starkly dramatic because it is both a summons away from his former life and an invitation to a new relationship that must be based entirely on trust." ${ }^{17}$ But for the ancient people, "to leave one's home and break away from one's ancestral bonds was almost impossible."18 Nevertheless, Abraham responded unwaveringly in faith, in complete obedience to God. The Bible underlines it: "So Abram went, as the Lord had told him; and Lot went with him. Abram was seventy-five years old when he departed from Haran" (Gen 12:4). Abraham took Sarah his wife and Lot his nephew and all their dependents and possessions and they came to Canaan. Here God appeared to him, promised the gift of the land of Canaan to his descendants and Abraham finally built there an altar to the Lord where he called the Lord's name (Gen 12:5-9).

14 L. HICKS, "Abraham", in The Interpreters Dictionary of the Bible, Vol. I, 14.

15 HICKS, "Abraham", 15.

${ }^{16}$ WILLIAMS, New Concise Bible Dictionary, 3.

17 L. BOADT, "Genesis", in W.R. FARMER - al., ed., The International Biblical Commentary: A Catholic and Ecumenical Commentary for the Twenty First Century (Collegeville: The Liturgical Press, 1998) 372.

18 P. M. IGBO, Introduction to the Old Testament Books and Pseudepigrapha (Enugu: Claretian Publications, 2020) 120.

@ECRTD-UK: https://www.eajournals.org/ 
Global Journal of Arts, Humanities and Social Sciences

Vol.10, No.1, pp.54-63, 2021

Print ISSN: 2052-6350(Print)

Online ISSN: 2052-6369(Online)

Abraham loved God, but was worried that God had not given him and Sarah a son. Rather, Ishmael, who was born of Hagar, the slave, was to be his heir (Gen 15:1-3). But God responded to him, saying that as the stars of the heavens are innumerable, "so shall your descendants be" (Gen 15:5). This promise of a son was repeated in Gen 17:15-21. In fact, here God told Abraham that the name of the son to be born to him would be Isaac: "God said, 'No, but Sarah your wife shall bear you a son, and you shall call his name Isaac. I will establish my covenant with him as an everlasting covenant for his descendants after him" (Gen 17:20). Regarding this promise, the Bible strongly remarks in favour of Abraham: "And he believed the Lord; and he reckoned it to him as righteousness" (Gen 15:6).

The word "righteousness" is hq")d"c. (șĕdāqah) in Hebrew, from the root qde, meaning "to be communally faithful, beneficial." 19 Normally, righteousness is defined in terms of moral conduct (cf. for example, Ezek 18:5). But here, it is Abraham's faith, his right response to God's revelation, which is counted for righteousness. As Wenham urges, "righteousness" normally results in right action and, as the rest of the story in the book of Genesis makes plain, Abraham's faith leads to righteous action, for example, regarding Sodom and Gomorrah in Gen 18,19. Nevertheless, it is only here, in the entire OT, that faith is counted as righteousness. ${ }^{20}$ This marks the unique faith of Abraham.

This promise of a son was again repeated to Abraham and Sarah when God visited them in the form of three men (Gen 18:9-8), with the assurance that the promise would materialize the next "spring" (Gen 18:9-15). Actually, God tested the faith of Abraham and Sarah, coming "at the time when they were past all expectation of normal procreation (vv. 12-13) and promising them a son of their own." 21 By remaining strong and faithful to God in the face of such an improbable promise, Abraham further showed the solidity of his faith in God. Even when Isaac was eventually born, as God had promised, Abraham was already a hundred years old (Gen 21:1-7)! His unhesitating readiness to offer Isaac to God in obedience to God's instruction, finally and supremely marked Abraham out as unique in faith before God and all who believe in Him (Gen 22:2-19). To these believers, especially Christians, Abraham is, indeed, a challenge!

\section{The Nigerian Christian Context}

Here, I would briefly touch on the general context in which the Nigerian Christian lives - political, social, economic and religious - as it inevitably influences his/her Christian faith and its ultimate practice.

Like the majority of people in this country, most Christians are daily struggling to make ends meet, in the face of abject poverty and extreme deprivation. As this writer pens down these lines, many families can no longer boast of three square meals a day, as galloping inflation is made more

${ }^{19} \mathrm{~K} . \mathrm{KOCH}$, "qdc" in E. JENI - C. WESTERMANN, Theological Lexicon of the Old Testament, Vol. 2 (Peabody: Hendrickson, 1997) 1046.

${ }^{20}$ G. J. WENHAM, Genesis 1-15, (WBC 1; Nashville: Thomas Nelson, 1987) 330.

${ }^{21}$ HICKS, "Abraham", 18.

@ECRTD-UK: https://www.eajournals.org/

Journal level DOI: https://doi.org/10.37745/gjahss.2013 
Global Journal of Arts, Humanities and Social Sciences

Vol.10, No.1, pp.54-63, 2021

Print ISSN: 2052-6350(Print)

Online ISSN: 2052-6369(Online)

complex by the continued weakness in the purchasing value of our local currency, the Naira. Corruption is rampant. Insecurity has become the order of the day. Christians in some parts of Northern Nigeria are not free to practice their faith owing to this enduring security situation - and the government seems ultimately incapable of dealing with it! All these inevitably precipitate a near-total loss of faith, by the people, in the government and its agencies, as well as in the political clime in general. But $\mathrm{I}$ have also written about this elsewhere in greater detail. ${ }^{22}$

On its own part, Christianity in this part of the world is still young - just over a hundred years of age. Precisely speaking, even though there had been some attempts before then, ${ }^{23}$ it was only in December 5, 1885, that the missionaries really came to Igboland, with Fathers Lutz and Horne landing at the Onitsha Warf. ${ }^{24}$ They settled and began work in earnest. But the Church Missionary Society (C.M.S.), together with the Royal Niger Company, was already there, a little earlier. Notably, however, African Traditional Religions, a "part and parcel of the whole fabric of African cultural life," 25 were already in existence in Africa and widely practiced, long before this time. Hence, many converts to Christianity from these traditional religions have retained some aspects of their old religion, as Christians, even with the passage of time. For instance, the African Independent Churches actually broke out of the mainline Churches at the end of the $19^{\text {th }}$ century. Their aim is to bring about a sort of Christianity where elements from African Traditional Religion would be mainly accepted, engendering greater responsiveness to the felt need of the African Christians: "For instance sacrifices to spirits, rivers, hills and uncanny places and the use of charms or medicine are strong components of many African Churches. These are used in spite of the proclamation of the Churches to be Christian, and this belies the unapologetic syncretism of these movements." 26 This is serious! Yet, it remains part of the history of Christianity in this part of the world!

\section{Relevance of Abraham's Faith to the Christian}

From all that have been explained so far about Abraham, it becomes clear that he is a very outstanding biblical figure. ${ }^{27} \mathrm{He}$ is, therefore, highly valued by all religions which acknowledge God's revelation of himself in the OT, especially Judaism, Christianity and Islam. God's choice of

22 E. U. DIM, The Christian and the Governing Authorities (Rom. 13,1-7): The Nigerian Situation (Inauguration Lecture Series no. 6) (Nimo: Rex Charles \& Patrick, 2009) 19-29.

${ }^{23}$ Cf. G. EHUSANI, "The Christian Faith and Mission in Africa: Prospects and Challenges", in M. N. EZEH, ed., Christian Faith and Mission in Eastern Nigeria: The Life and Mission of Archbishop Charles Heerey C.S.Sp (1890-1967) 8-9.

${ }^{24}$ C. A. OBI, ed., A Hundred Years of the Catholic Church in Eastern Nigeria1885 - 1985

(Onitsha: Africana-Fep, 1985) 12.

25 E. I. METUH, African Religions in Western Conceptual Schemes: The Problem of Interpretation (Studies in Igbo Religion) (Jos: IMICO Press, 1991) vii.

${ }^{26}$ J. O. OGUEJIOFOR, "African Theologians and the Challenge of Miracle Christianity", in The Nigerian Journal of Theology, Vol. 15 (June, 2001) 39.

${ }^{27}$ P. ALEXANDER - al., ed., The Lion Encyclopedia of the Bible (Tring: Lion Publishing, 1986) 195.

@ECRTD-UK: https://www.eajournals.org/ 
Global Journal of Arts, Humanities and Social Sciences

Vol.10, No.1, pp.54-63, 2021

Print ISSN: 2052-6350(Print)

Online ISSN: 2052-6369(Online)

Israel as his special people began with him and continued throughout the OT, especially through Moses, the judges, the kings and the prophets. It then reached its climax in Jesus Christ in the NT with the result that all who are baptized - all Christians - become God's adopted children through Jesus - and hence, heirs to Abraham's promise.

Thus, in the OT, Israel was called the "people of the God of Abraham" (Ps 47:9) or the "offspring of Abraham" (Ps 105:6; Isa 41:8) and Abraham was Israel's father (Isa 51:2; 63:16). He was not just God's servant (Gen 26:24; Ps 105:42), but his friend as well (2Chron 20:7; Isa 41:8). The letter to the Hebrews aptly links God's plan of salvation in both parts of the Scriptures when it remarks: "In many and various ways God spoke of old to our fathers by the prophets; but in these last days he has spoken to us by a Son, whom he appointed the heir of all things, through whom also he created the world" (Heb 1:1-2). In the NT, therefore, Abraham also becomes the father of all those who, after the Spirit, share in his faith (Luke 13:16; 16:24; 19:9; Acts 13:26; Rom 11:1 (Rom 4:16; Gal 3:29). Christians are the "children of promise" (Gal 4:28) and its proper heirs (Gal 3:29). God is the "God of Abraham" (Mark 12:26; Acts 7:32) and Abraham, his friend (Jas 2:23) and lives in heaven (Luke 16:22; John 8:56.58). In short, Abraham is "a monumental figure of faith:"

... the strongest NT picture of Abraham portrays him as a monumental figure of faith. In his call, in his waiting upon the fulfillment of the promises and preeminently in the sacrifice of Isaac, Abraham patiently endured all tests "by faith".... This life of faith stands as a model for all Christians (Gal 3:6-9), and, by implication, is proto-typical of Christ's life of perfect obedience. ${ }^{28}$

It is, therefore, little wonder why the Roman Canon (Eucharistic Prayer I) unequivocally names Abraham "our father in faith" during the celebration of the Eucharist. He is a model in faith, indeed.

\section{Challenge to Christians in Nigeria}

It is clear by now, I believe, that the most striking aspect of Abraham is his faith in God. This faith and his manifest trust in God (cf. Gen 22:8) made him find strong favour in God's sight, ${ }^{29}$ that faith being credited to him by the same God as righteousness (Gen 15:6; cf. Rom 4:1-3), as already explained. The letter to the Hebrews also goes further to outline these special aspects of the faith of Abraham - he left his homeland unhesitatingly, at God's command, sojourned in a foreign land and accepted to offer Isaac his only son in sacrifice to God (Heb 11:8-19). It would also be important to stress the fact that, in all his relationship with God, as we have taken time to analyze above, Abraham was tested and this testing "was not peripheral to but foundational for the relationship." ${ }^{30}$ His life of faith and manifest steadfastness to God are simply worthy of emulation by all Christians in a similar foundational manner.

28 HICKS, "Abraham", 20.

${ }^{29}$ A. R. MILLARD, "Abraham", in The Anchor Bible, Vol. I (New York: Doubleday, 1992) 35.

30 J. P. HEALEY, "Faith", in The Anchor Bible Dictionary, Vol II (New York: Doubleday, 1992) 746.

@ECRTD-UK: https://www.eajournals.org/ 
To that effect, it needs to be observed that one of the most basic difficulties which Christians face in this part of the world, in the practice of their faith, is what one may call the crisis of faith: Many people are Christians. They are baptized. But in the full and unalloyed practice of their faith, they are found wanting in one way or another. In the midst of very serious difficulties, they slip back to pagan practices regarding charms, fetishes and general syncretism. A recent example is the case of a newly wedded couple one of whom (the bridegroom) mysteriously went missing the day after the wedding. When the bride and the other members of the family had grown tired of searching for him, the man suddenly reappeared after four days - completely unaware of what had happened to him and where he had been all the while! As he was not forthcoming with any meaningful explanation, despite all concerned promptings and probings, the family resorted to consulting a traditional medicine man (dibia). The dibia, after they had paid him some money, made his usual divination. He then told the bridegroom, in a proverb, that he, the groom, should be aware of the cause of his ordeal. Consequently, after strongly rebuking the groom, the dibia insisted that the groom was the only one who could tell the entire family the cause of his ordeal - and they all went home seeming pacified!

Why should this be the case at all, one may ask? What extra ordinary thing has the so called dibia done in this case as to warrant any trust on him at all? What sort of "Christians" are these who had visited this dibia? No wonder many young Christians, these days, go back to clear neopaganism, openly and lavishly celebrating pagan festivals. They even brazenly and frontally oppose the Church and its teachings regarding these practices and their way of life whenever attempts are made at correcting those excesses. One is left with the worrisome conclusion that neo-paganism "is gradually growing like wild fire particularly among the youthful population" in this part of the world. ${ }^{31}$

For some Christians, therefore, the faith they profess is only skin-deep, a situation that seems to have grown worse through the syncretic influence of the African Independent Churches, which has already been noted above, as well as Pentecostalism. But, as is already very clear, this situation greatly compromises genuine Christian faith and praxis. It rather favours and emboldens the Prosperity Gospel in its projection of prosperity rather than the kingdom of God and its righteousness (Matt 6:33) as the focus of true Christian life. ${ }^{32}$ A situation of crisis in faith regarding true and authentic Christianity is thereby heavily precipitated.

Still, for many others, the Christian faith is for miracles! Strongly aware that Jesus worked many miracles during his earthly life and is still doing so in the post Easter Church, this group seeks to find answers to all life's problems, both material and spiritual, from Christianity. They, therefore, frequent prayer houses, healing ministries and crusades in the utopic search for these miracles,

${ }^{31}$ P. O. OKAFOR, "Editorial: The Church and the Challenge of Neo-Paganism in SouthEastern Nigeria", in Ministerium - A Journal of Contextual Theology, Vol. 6 (December, 2020) v.

32 L. N. NWANKWO, "African Christianity and the Challenge of Prosperity Gospel", in Ministerium - A Journal of Contextual Theology, Vol. 5 (December, 2019) 11. 
attracted by the so-called "powerful" clergymen and "men of God". At such centres, these votaries tend to play more active and dedicated roles than they do in their parishes of origin or abode. Failure to obtain their wished-for intention in one prayer house or ministry, sees them moving to another, in what may seem an endless search at the end of it all.

But the story does not end there! This is because what constitutes a disturbing point of reflection for many Christians is this serious observation by Oguejiofor:

There is now a slow inroad of all the elements that were initially criticised in the African Independent Churches, from their liturgy to their belief framework. The view that no one goes to prayer houses under normal circumstances has drastically changed, especially with prayer ministries becoming a feature of the mainline Churches, especially the Catholic Church in Africa. ${ }^{33}$

The results of all the above are not difficult to see or to imagine: deep-seated doubts and uncertainties in the lives of faith of many of our Christians, to say the least. Hence, Igwegbe surmises that one can hear, today, strong echoes of the big question that tormented the Church in Antioch at the early stage of Christianity as: Who saves? Jesus or the Law? The old religion or the new faith? The traditions of the ancestors or the eschatological Word spoken in Jesus? The Catholic Church or the Pentecostal communities? Which is the genuine expression of the true faith and worship - the Catholic tradition or the new slogans and slangs, new prayer formula and gestures invented by the new groups? ${ }^{34}$

One does not forget the issue of childlessness which was also the difficult lot of Abraham and Sarah his wife. Abraham strongly believed and trusted God for a change, as God gave him repeated promises in this regard, as already noted. Isaac was eventually born in extraordinarily rare circumstances. Yet Abraham was asked by the same God to sacrifice the same Isaac, to which he unhesitatingly obliged, before God himself stopped the impending sacrifice! I believe that it may be needless to dwell much on this issue, as every African knows the woes and torments which befall childless couples in almost all African cultures - but that was similar to the oriental culture of Abraham at the time of the incident. ${ }^{35}$ Yet Abraham remained faithful and trustingly steadfast to God to the end. And God did not disappoint him.

Consequently, Abraham strongly challenges the Nigerian Christians in the dedicated practice of our faith. As he steadfastly believed and obeyed God in all circumstances, as we have already seen, so he challenges us to follow suit. He challenges the Church to maintain constant and enduring catechesis for the People of God, so that they could keep

33 OGUEJIOFOR, "African Theologians and the Challenge of Miracle Christianity", 47.

34 I. O. IGWEGBE, "Evangelisation in the New Millenium: Challenges for the Church", in The Nigerian Journal of Theology, Vol. 15 (June, 2001) 9.

${ }^{35}$ IGBO, Introduction to the Old Testament Books and Pseudepigrapha, 120. 
growing continually in their faith. This appeal on the part of the Church is really urgent. For example, regarding the causes for neo-paganism among our young Christians today, Okafor mentions the search for security, spiritual powers, right relationship with the transcendental world and material benefits to existential problems. But he then adds: "and above all the inability of the Church in her mission and worship to provide enough meaning and motivation for strong religious commitment." 36 The Church cannot afford to fail in this regard as she has received the divine and compelling mandate to preach the Gospel to all nations (Matt 28:18-20).

\section{CONCLUSION}

Abraham has really shown himself to be our father in faith. He is a challenge to all Christians, particularly those in Nigeria. He has helped to bring to actuality God's plans of salvation for the whole world, a plan that began from the OT and reached its climax in Jesus, the Christ, in the NT. Therefore, "the heirs of Abraham become the universal covenant community of the NT, there being neither Jew nor Greek in Christ." 37

Consequently, we Christians should try to imitate Abraham in his faith as we follow Jesus our Lord. In fact, Abraham's legacy in faith strongly challenges us, Christians, to do this. It also strongly challenges all the established Churches never to rest on their oars in providing the requisite catechesis to all their members for the constant rejuvenation of their faith as well as its growth. This has been the main point of this paper. Hence, to keep our faith alive and dynamic, we must always profess it, celebrate it and renew it. It is hoped that this paper would help us, even if only minimally, to always realize these goals.

${ }^{36}$ OKAFOR, "Editorial: The Church and the Challenge of Neo-Paganism in South-Eastern Nigeria", vii.

${ }^{37}$ M. G. KLINE, "Genesis" in G. GUTHRIE - al., ed., New Biblical Commentary (Third Edition) (Leicester: Inter-Varsity, 1970) 95. 